\section{Invisible borders}

\section{UK immigration rules are perceived as being tougher than they really are.}

$\mathrm{F}$ or an international business such as science, there is no true immigration - just movement. National borders are notional; passports indicate where someone was born, not where they belong or where they can do the most good.

Politicians, and much of the public, do not see immigration like that. They see strain on services and overcrowded job markets and, in a few cases, some use these legitimate concerns as thin masks for prejudice, xenophobia and racism. As economic difficulties bite, governments frequently promise to 'get tough' on immigration, often turning a blind eye to the benefits of an influx of people as they do so.

In 2010 the warnings were stark. The United Kingdom's new, firmer stance on immigration could "spell disaster for UK science", warned the Royal Society of Chemistry. Nobel laureates voiced similar concerns in the national press. The Campaign for Science and Engineering (CaSE) mobilized to keep the United Kingdom 'open for business', with calls to give priority to visa applications from overseas scientists.

Nature too spoke out about the risk posed by crude measures to curb immigration, which could potentially scupper the ability of some of Britain's leading research laboratories to recruit the best people (see Nature 468, 346; 2010).

To the UK government's credit, it heeded the warnings and made exceptions for scientists, loosening the rules to grant them entry under circumstances that would cause other migrants from different professions to be turned away. A new scheme for 'exceptionally talented' scientists and artists was created. Some 700 scientists and 300 artists a year would be allowed in. Problem solved?

Apparently not. The United Kingdom is again in the throes of a political debate about the benefits and problems of immigration, and science lobby groups are again worried that researchers will be caught in the crossfire. As we report on page 14, these groups recently badgered the Home Office at a meeting on the subject, and some made the same doom-laden predictions.

Unfortunately, the campaigners are on less solid ground this time. The exceptional-talent route has mainly been exceptional in its

underuse: the latest figures show that by June 2013 only 89 people (both scientists and artists) had used it. Indeed, one researcher told Nature that his visa is so rare that "when I re-enter the UK, the border staff always comment 'Oh, I've never seen one of those'".

Hundreds of places on the scheme remain unfilled. And other concessions remain. In fact, scientists are in a better position than just about anyone else who wishes to move to and work in the United Kingdom, with the possible exception of international soccer stars. And even there, similar rhetoric about the effect on domestic talent has led to footballers

"Scientists are in a better position thanjust about anyone else who wishes to move to and work in the United Kingdom."

\section{Tow to keep happy the thou}

being recently refused work permits.

The situation is not perfect - far from it. Many academics have justifiable gripes with the UK Border Agency and its visa processes - a postdoc forced out of the country nearpenniless perhaps, or an eminent colleague scheduled to deliver a keynote speech at a conference turned away. Such difficulties are common throughout most of the world. The United States is currently grappling with how to keep happy the thousands of scientists who are unable to obtain green cards for permanent residency every year.

'Highly skilled' migrants are usually singled out for praise when politicians confront immigration, but the subject is a notorious minefield and is hard for politicians to navigate with rational arguments. Image, perceived approach and rhetoric about being 'tough' buy popularity here perhaps more than in any other political sphere - whatever the evidence may say.

After the recent meeting with the Home Office, CaSE said that such "messaging" from the UK government about making it harder for immigrants could itself deter leading scientists from coming. That could explain, for example, why piles of the exceptional-talent visas remain unused in the drawers of the Border Agency. But seen another way, the government is making it possible for scientists to come, whereas it is the campaigners who organize open letters and give media-friendly briefings about how hard it is for them to do so. Pressure groups have one weapon - pressure - and it is one that can be as crude as any political rhetoric. If messaging is the problem, then the campaigners must be cautious about the message that they themselves send.

There are real problems with the movement of scientists across borders, and campaigners are right to highlight them. Nature will continue to press for such obstacles to be removed - the real and the rhetorical.

\section{Trick of the light}

The Amazondoesn'tabsorbextra carbonin the dry seasonafter all. It can become a carbon source.

$\mathrm{B}$ udding biologists learn early the apparently simple holy trinity of ingredients for photosynthesis: carbon dioxide, water and light. In truth, the equation is a little more complicated than that, and when photosynthesis proceeds on a truly massive scale, these complications can have huge implications.

Take, for example, the world's largest mass of concentrated photosynthesis: the Amazon rainforest of South America. Scientists have long struggled to work out whether the rate of photosynthesis there is controlled by the available amount of water or of sunlight. (Over seasonal timescales, that is - on a 24 -hour cycle, it is controlled by the availability of sunlight.)

The uncertainty was triggered by a surprising result from satellite images, which seemed to show that Amazon forests became greener during the dry season, and greenest of all during years of severe drought such as 2005 (S. R. Saleska et al. Science 318, 612; 2007). More green means more photosynthesis, so this result suggested that it was the availability of light, and not water, that was the controlling factor. Clear skies and sunny weather were more important than moisture in the soil.

In a study published on Nature's website today (D. C. Morton et al. Nature http://dx.doi.org/10.1038/nature13006; 2014), researchers show that this is, literally, an illusion. The forest does not become greener during dry periods at all. It just looks that way when the sensor and the Sun are both in the south of the sky. It is not photosynthesis that drives the apparent greening of the forest at such times, but a lack of shadow.

The finding drags attention away from the importance of light in the Amazon's photosynthesis equation, and towards the need for water. But what of the third point of the triangle, carbon dioxide? There is uncertainty there too: this time over whether in years of drought, the trees will switch from being a net carbon sink to a source, which could worsen global warming. A second study of the Amazon, $\rightarrow$ NATURE.COM To comment online, click on Editorials at: go.nature.com/xhunqv on page 76 , offers the latest data on this debate, and the news is not good. Fire and drought can indeed make the Amazon a net source of atmospheric carbon - whatever colour it is at the time. 